\title{
ENTREPRENEUR
}

Jurnal Bisnis Manajemen Dan Kewirausahaan

Program Studi Manajemen Fakultas Ekonomika dan Bisnis Universitas Majalengka

Published every January and July e-ISSN : (Proses), p-ISSN: 2723-1941

Available online http://ejournal.unma.ac.id/index.php/entrepreneur

\section{Pengaruh Pengendalian Internal dan Kesesuaian Kompensasi terhadap Kecenderungan Kecurangan Akuntansi pada Perumda BPR Majalengka}

\author{
Wulan Riyadi \\ Fakultas Ekonomika dan Bisnis Universitas Majalengka \\ Email : wulanriyadi@unma.ac.id
}

\begin{abstract}
Accounting fraud related to corruption, an unusual action taken is to manipulate the recording, omission of documents, and mark ups that are detrimental to the country's finances or economy. Internal control is a representative of all activities within the organization that must be carried out to provide adequate confidence regarding the achievement of effective and efficient operational control objectives, the reliability of financial statements, and compliance with the law. Compensation is often called an award and can be defined as a form of appreciation given to employees as a remuneration for the contribution they make to the organization. This study aims to determine the effect of internal control and the suitability of compensation for trends in accounting fraud. The method used in this research is to use descriptive and verification analysis. The population in this study were 36 people using puposive sampling techniques. Data collection technique is a survey with a questionnaire. Data instrument testing is done by using validity, reliability and data normality tests. Analysis of the data is the correlation of determination and hypothesis testing using the $t$ test and $F$ test. The data is processed using SPSS Version 21 and Microsoft Excel 2007. The results of this study indicate that internal control affects the tendency of accounting fraud. suitability of compensation affects the tendency of accounting fraud. Internal control and suitability of compensation affect the tendency of accounting fraud.
\end{abstract}

Keywords:

Internal Control, Compliance Compensation, Tendency of Accounting Fraud. 


\section{ENTREPRENEUR}

Jurnal Bisnis Manajemen Dan Kewirausahaan

Program Studi Manajemen Fakultas Ekonomika dan Bisnis Universitas Majalengka

Published every January and July e-ISSN : (Proses), p-ISSN: 2723-1941

Available online http://ejournal.unma.ac.id/index.php/entrepreneur

\section{PENDAHULUAN}

Seiring dengan berkembangnya kompleksitas bisnis dan semakin terbukanya peluang usaha dan investasi menyebabkan resiko terjadinya kecurangan pada perusahaan semakin tinggi. Kecenderungan Kecurangan Akuntansi (KKA) telah mendapatkan banyak perhatian media sebagai dinamika yang sering terjadi. Ikatan Akuntansi Indonesia menjelaskan kecurangan akuntansi sebagai salah saji yang menimbulkan kecurangan akuntansi sebagai salah saji atau menghilangkan secara sengaja jumlah atau pengungkapan dalam laporan keuangan dan salah saji yang timbul dari perlakuan tidak semestinya terhadap aktiva (sering kali disebut dengan penyalahgunaan atau penggelapan).

Berkaitan dengan pencurian aktiva entitas yang berakibat laporan keuangan tidak disajikan sesuai dengan prinsip akuntansi yang berlaku umum di Indonesia. Indikasi adanya kecenderungan kecurangan akuntansi dapat dilihat dari bentuk kebijakan yang disengaja dan tindakan yang bertujuan untuk melakukan penipuan atau memanipulasi yang merugikan pihak lain. kecurangan akuntansi berkaitan dengan korupsi, tindakan yang tidak lazim dilakukan adalah memanipulasi pencatatan, penghilangan dokumen, dan mark up yang merugikan keuangan atau perekonomian negara. Kecenderungan kecurangan akuntansi dapat dikatakan sebagai tendensi korupsi dalam definisi dan terminologi karena keterlibatan beberapa unsur yang terdiri dari fakta-fakta menyesatkan, pelanggaran aturan atau penyalahgunaan kepercayaan dan omisi fakta kritis (Adelin, 2017).

Menurut Andi (2014), kecurangan dapat diartikan sebagai penipuan dibidang keuangan yang disengaja, yang dimaksudkan untuk mengambil aset atau hak pihak lain. Dalam melakukan kecurangan, setiap orang memiliki motivasi yang beraneka ragam. Salah satu teori yang menjelaskan tentang motivasi seseorang dalam melakukan kecurangan adalah teori fraud triangle yang dikembangkan oleh Zulkarnain (2015). Teori ini mengatakan bahwa "kecurangan akuntansi disebabkan oleh tiga faktor, yaitu Kesempatan (Opportunity), Tekanan (Pressure), dan Rasionalisasi (Rationalization). Adapun proksi dari tiga faktor yang memotivasi seseorang melakukan kecurangan akuntansi yaitu penegakan peraturan, keefektifan sistem pengendalian internal, asimetri informasi, keadilan prosedural, keadilan distributif, persepsi mengenai komitmen organisasi dan budaya etis organisasi.

Pengendalian internal dan kesesuaian kompensasi sebagai faktor yang dapat mempengaruhi kecenderungan kecurangan akuntansi. Didalam penelitian ini pengendalian internal adalah respresentatif dari keseluruhan bagian didalam organisasi yang harus dilakukan untuk memberikan keyakinan yang memadai tentang pencapaian tujuan pengendalian operasional yang efektif dan efisien, keandalan laporan keuangan, serta kepatuhan terhadap hukum (Andi 2014). Selain pengendalian internal, kesesuaian kompensasi juga merupakan faktor yang mempengaruhi seseorang melakukan kecurangan. Kompensasi seringkali disebut penghargaan yang diberikan kepada karyawan sebagai balas jasa atas kontribusi yang mereka berikan kepada organisasi (Friskilla 2014). Nih luh putu (2015) menyatakan bahwa kompensasi merupakan balas jasa yang diberikan organisasi kepada karyawan, yang bersifat financial maupun non financial pada periode yang tetap. 


\section{ENTREPRENEUR}

\section{Jurnal Bisnis Manajemen Dan Kewirausahaan}

\section{Program Studi Manajemen Fakultas Ekonomika dan Bisnis Universitas Majalengka}

Published every January and July e-ISSN : (Proses), p-ISSN: 2723-1941

Available online http://ejournal.unma.ac.id/index.php/entrepreneur

\section{KERANGKA TEORITIS DAN HIPOTESIS}

Adelin (2015) mengemukakan bahwa

Representatif dari keseluruhan kegiatan didalam organisasi yang harus dilaksanakan, dimana proses yang dijalankan oleh dewan komisaris ditujukan untuk memberikan keyakinan yang memadai tentang pencapaian tujuan pengendalian operasional yang efektif dan efisien, keandalan laporan keuangan, dan kepatuhan terhadap hukum yang berlaku. Pengendalian yang kuat akan mampu menurunkan tingkat kecenderungan kecurangan akuntansi, jika pengendalian internalnya lemah maka kecenderungan kecurangan akuntansinya akan semakin besar.

$\begin{array}{rrr}\text { kesesuaian } & \text { kompensasi } & \begin{array}{r}\text { adalah } \\ \text { kecocokan }\end{array} \text { dan }\end{array}$
karyawan/pegawai/pekerja atas apa imbalan jasa yang diterima karyawan dari perusahannya atas kerja samanya dalam perusahaan tersebut, baik berupa uang ataupun barang. Dan dengan adanya kesesuaian kompensasi diharapkan dapat mencegah dan meminimalisasikan tindakan kecurangan didalam instansi (Hasibuan, 2016).

kecenderungan kecurangan akuntansi adalah keinginan untuk melakukan segala sesuatu untuk memperoleh keuntungan dengan cara yang tidak jujur seperti menutupi kebenaran, penipuan, manipulasi, kelicikan yang dapat berupa salah saji atas laporan keuangan, korupsi, dan penyalahgunaan aset (Abdul Halim, 2015).

Hipotesis Penelitian

Berdasarkan rumusan masalah dan pemaparan yang sudah dijelaskan, maka peneliti mengajukan hipotesis sebagai berikut:

H1 : Pengendalian Internal berpengaruh terhadap Kecenderungan Kecurangan Akuntansi.
H2 : Kesesuaian Kompensasi berpengaruh terhadap Kecenderungan Kecurangan Akuntansi.

H3 : Pengendalian Internal dan Kesesuaian Kompensasi berpengaruh terhadap Kecenderungan Kecurangan Akuntansi.

\section{METODELOGI PENELITIAN}

Metode analisis yang digunakan dalam penelitian ini adalah metode survei. Variabel independen dalam penelitian ini yaitu :

Pengendalian Internal

Sukrisno Agoes (2014:100) yang mendefinisikan pengendalian internal sebagai :

"Suatu proses yang dijalankan oleh dewan komisaris, manajemen, dan personel lain entitas yang di desain untuk memberikan keyakinan memadai tentang pencapaian lima golongan tujuan berikut ini : Lingkungan pengendalian internal, penilaian risiko, prosedur pengendalian, informasi dan komunikasi, pemantauan".

Kesesuaian Kompensasi

Imbalan jasa yang diterima karyawan atas hasil kerja karyawan tersebut pada organisasi. Gaji, upah, Kompensasi bisa berupa fisik maupun non fisik dan harus dihitung dan diberikan kepada karyawan sesuai dengan pengorbanan yang telah diberikannya kepada organisasi tempat ia bekerja. (Kenneth, 2014). akuntansi

kecenderungan kecurangan

Kecenderungan untuk manipulasi, Kecenderungan untuk penghilangan transaksi atau informasi, Kecenderungan untuk penerapan prinsip akuntansi, Kecenderungan untuk pencurian terhadap aktiva, Kecenderungan untuk melakukan 


\section{ENTREPRENEUR}

\section{Jurnal Bisnis Manajemen Dan Kewirausahaan}

\section{Program Studi Manajemen Fakultas Ekonomika dan Bisnis Universitas Majalengka} Published every January and July e-ISSN : (Proses), p-ISSN: 2723-1941

Available online http://ejournal.unma.ac.id/index.php/entrepreneur

penyajian laporan keuangan yang disertai dokumen palsu.

Populasi penelitian adalah karyawan PERUMDA BPR Majalengka yang berjumlah 146. Sampel penelitian ini yaitu 36 karyawan PERUMDA BPR dengan teknik purposive sampling Jenis data yang digunakan dalam penelitian ini adalah data kuantitatif dengan menggunakan data primer yang diperoleh dari responden. Adapun pengujian terdiri dari uji validitas dan reliabilitas, uji asumsi klasik, analisis regresi berganda, analisis koefisien determinasi, dan uji hipotesis

Metode penelitian ditulis bentuk paragraf berisi desain penelitian yang digunakan (metode, jenis data, sumber data, teknik pengumpulan data, populasi, sampel, operasionalisasi variabel, teknik analisis data, pengukuran variabel) yang ditulis dalam bentuk paragraf mengalir (tidak dibuat numbering).

\section{HASIL DAN PEMBAHASAN}

Tabel 1 Hasil Uji Normalitas

One-Sample Kolmogorov-Smirnov Test

\begin{tabular}{|ll|r|}
\hline & & $\begin{array}{r}\text { Unstandardiz } \\
\text { ed Residual }\end{array}$ \\
\hline $\mathrm{N}$ & Mean & 36 \\
Normal Parameters & a,b & Std. \\
& Deviation & 1,0133786900 \\
Most Extreme & Absolute &, 118 \\
Differences & Positive &, 118 \\
Kolmogorov-Smirnov Z & Negative &,- 093 \\
Asymp. Sig. (2-tailed) &, 705 \\
\hline
\end{tabular}

a. Test distribution is Normal.

b. Calculated from data.

Sumber : Output SPSS 21 (Diolah Sendiri, 2021)

Tabel 2 Hasil Uji Analisis Regresi Linear Berganda

\begin{tabular}{|c|c|c|c|c|c|c|c|c|}
\hline \multirow{3}{*}{\multicolumn{2}{|c|}{ Model }} & \multicolumn{4}{|c|}{ Coefficients ${ }^{2}$} & & \multicolumn{2}{|c|}{ Collinearity Statistics } \\
\hline & & \multicolumn{2}{|c|}{$\begin{array}{l}\text { Unstandardized } \\
\text { Coefficients }\end{array}$} & \multirow{2}{*}{$\begin{array}{c}\text { Standard } \\
\text { ized } \\
\text { Coeffici } \\
\text { ents } \\
\text { Beta }\end{array}$} & \multirow[t]{2}{*}{$\mathrm{T}$} & \multirow[t]{2}{*}{ Sig. } & \multicolumn{2}{|c|}{ Collinearity Statistics } \\
\hline & & B & $\begin{array}{c}\text { Std. } \\
\text { Error }\end{array}$ & & & & $\begin{array}{l}\text { Toler } \\
\text { ance }\end{array}$ & VIF \\
\hline \multirow{5}{*}{1} & (Constant) &,- 719 & 1,089 & &,- 660 &, 514 & & \\
\hline & Pengendalian &, 693 &, 067 &, 337 & 10,30 &, 000 & 878 & 1,139 \\
\hline & Internal & & & & 1 & & & \\
\hline & Kesesuaian &, 646 &, 026 &, 815 & 24,93 &, 000 & 878 & 1,139 \\
\hline & Kompensasi & & & & 2 & & & \\
\hline
\end{tabular}

a. Dependent Variable: Kecenderungan Kecurangan Akuntansi 


\section{ENTREPRENEUR}

Jurnal Bisnis Manajemen Dan Kewirausahaan

Program Studi Manajemen Fakultas Ekonomika dan Bisnis Universitas Majalengka Published every January and July e-ISSN : (Proses), p-ISSN: 2723-1941

Available online http://ejournal.unma.ac.id/index.php/entrepreneur

Tabel 3 Uji Koefisien Determinasi Model Summary ${ }^{b}$

\begin{tabular}{|c|c|c|c|c|c|c|c|c|c|}
\hline \multirow{2}{*}{$\begin{array}{l}\text { Mo } \\
\text { del }\end{array}$} & \multirow[t]{2}{*}{$\mathrm{R}$} & \multirow{2}{*}{$\begin{array}{c}\mathrm{R} \\
\text { Squar } \\
\mathrm{e}\end{array}$} & \multirow{2}{*}{$\begin{array}{c}\text { Adjuste } \\
\text { d R } \\
\text { Square }\end{array}$} & \multirow{2}{*}{$\begin{array}{c}\text { Std. } \\
\text { Error of } \\
\text { the } \\
\text { Estimate }\end{array}$} & \multicolumn{5}{|c|}{ Change Statistics } \\
\hline & & & & & $\begin{array}{c}\text { R } \\
\text { Square } \\
\text { Change }\end{array}$ & $\begin{array}{c}\text { F } \\
\text { Chan } \\
\text { ge }\end{array}$ & df1 & $\mathrm{df} 2$ & $\begin{array}{c}\text { Sig. F } \\
\text { Change }\end{array}$ \\
\hline 1 & $984^{\mathrm{a}}$ & ,969 & ,967 & 1,04364 & ,969 & $\begin{array}{c}516,6 \\
41\end{array}$ & 2 & 33 &, 000 \\
\hline
\end{tabular}

Tabel 4 Hasil Uji Hipotesis

\begin{tabular}{|c|c|c|c|c|c|c|}
\hline \multicolumn{2}{|c|}{ Model } & $\begin{array}{c}\text { Sum of } \\
\text { Squares }\end{array}$ & $\mathrm{df}$ & $\begin{array}{c}\text { Mean } \\
\text { Square }\end{array}$ & $\mathrm{F}$ & Sig. \\
\hline \multirow{3}{*}{1} & Regression & 1125,426 & 2 & 562,713 & 516,641 &, $000^{b}$ \\
\hline & Residual & 35,943 & 33 & 1,089 & & \\
\hline & Total & 1161,368 & 35 & & & \\
\hline
\end{tabular}

Pengaruh Pengendalian Internal Terhadap Kecenderungan Kecurangan Akuntansi Pada PERUMDA BPR Majalengka

Berdasarkan hasil analisis dapat diketahui bahwa Pengendalian Internal berpengaruh terhadap Kecenderungan Kecurangan Akuntansi.

Hasil penelitian ini konsisten dengan penelitian Riska (2018), Ryan (2017), Yuliana (2015), Lutfi (2018), Maria (2017) dimana hasil penelitiannya menyatakan bahwa pengendalian internal berpengaruh negatif terhadap kecenderungan kecurangan akuntansi. Sehingga hal ini mendukung perumusan $\mathrm{H} 1$ bahwa pengendalian internal berpengaruh terhadap kecenderungan kecurangan akuntansi.

Hasil penelitian ini sejalan dengan teori menurut Committee of Sponsoring Organization of the Treadway Commision (2017) menjelaskan pengendalian yang kuat akan mampu menurunkan tingkat kecenderungan kecurangan akuntansi, jika pengendalian internalnya lemah maka kecenderungan kecurangan akuntansinya akan semakin besar.

Hal ini mengindikasikan bahwa pengendalian internal pada PERUMDA BPR Majalengka sudah baik sehingga kecenderungan kecurangan akuntansi nya rendah. Hal ini dilihat dari keandalan laporan keuangan, efisiensi dan efektifitas operasi serta kepatuhan terhadap hukum yang ada pada PERUMDA BPR Majalengka sudah baik. Dapat disimpulkan bahwa pengendalian internal mempunyai pengaruh terhadap kecenderungan kecurangan akuntansi pada PERUMDA BPR Majalengka.

Pengaruh Kesesuaian Kompensasi Terhadap Kecenderungan Kecurangan Akuntansi Pada PERUMDA BPR Majalengka

Berdasarkan hasil analisis dapat diketahui bahwa Kesesuaian Kompensasi berpengaruh terhadap Kecenderungan Kecurangan Akuntansi. Hasil penelitian ini konsisten dengan penelitian Ryan (2017), dimana hasil penelitiannya menyatakan 


\section{ENTREPRENEUR}

\section{Jurnal Bisnis Manajemen Dan Kewirausahaan}

\section{Program Studi Manajemen Fakultas Ekonomika dan Bisnis Universitas Majalengka}

Published every January and July e-ISSN : (Proses), p-ISSN: 2723-1941

Available online http://ejournal.unma.ac.id/index.php/entrepreneur

bahwa kesesuaian kompensasi berpengaruh negatif terhadap kecenderungan kecurangan akuntansi. Sehingga hal ini mendukung perumusan $\mathrm{H} 2$ bahwa kesesuaian kompensasi berpengaruh terhadap kecenderungan kecurangan akuntansi.

Hasil penelitian ini sejalan dengan teori yang dikemukakan oleh Veitzal (2014: 358) yang menyatakan bahwa kunci untuk memotivasi seseorang untuk berperilaku sedemikian rupa sehingga memajukan citacita suatu organisasi terletak pada cara pemberian insentif atau kompensasi oleh organisasi tersebut. Pemberian kompensasi kepada karyawan akan membantu perusahaan mencapai tujuan dan memperoleh serta menjaga karyawan dengan baik. Sebaliknya tanpa kompensasi yang cukup karyawan yang ada akan sangat mungkin untuk meninggalkan perusahaan. Akibat dari ketidakpuasan pembayaran yang dirasa kurang menghargai kinerja, meningkatkan keluhan-keluhan, mogok kerja dan mengarah pada tindakan - tindakan fisik dan psikologis seperti meningkatnya derajat ketidakhadiran dan kecurangan.

Hal ini mengindikasikan bahwa kesesuaian kompensasi yang baik dapat menurunkan kecenderungan seseorang melakukan kecurangan akuntansi pada

\section{SIMPULAN DAN IMPLIKASI}

Berdasarkan hasil penelitian dan analisis data yang dilakukan, maka dapat diperoleh kesimpulan sebagai berikut:

1. Pengendalian internal berpengaruh terhadap kecenderungan kecurangan akuntansi pada PERUMDA BPR Majalengka. Artinya menunjukan bahwa baik dan tidak baiknya pengendalian internal dapat menentukan tinggi rendahnya kecenderungan kecurangan akuntansi.

2. Kesesuaian kompensasi berpengaruh terhadap kecenderungan kecurangan akuntansi pada PERUMDA BPR
PERUMDA BPR Majalengka. Oleh karena itu ketika pemberian kompensasi baik kecenderungan kecurangan akuntansinya pun tinggi.

Pengaruh Pengendalian Internal dan Kesesuaian Kompensasi Terhadap Kecenderungan Kecurangan Akuntansi

Berdasarkan hasil analisis dapat diketahui bahwa Pengendalian Internal dan Kesesuaian Kompensasi berpengaruh terhadap Kecenderungan Kecurangan Akuntansi.

Hasil penelitian ini konsisten dengan penelitian Riska (2018), Ryan (2017), Yuliana (2015), Lutfi (2018), Maria (2017) dimana hasil penelitiannya menyatakan bahwa pengendalian internal dan kesesuaian kompensasi berpengaruh negatif terhadap kecenderungan kecurangan akuntansi. Sehingga hal ini mendukung perumusan $\mathrm{H} 3$ bahwa pengendalian internal dan kesesuaian kompensasi berpengaruh terhadap kecenderungan kecurangan akuntansi.

Hal ini mengidikasikan bahwa pengendalian internal yang baik dan diikuti dengan pemberian kompensasi yang sesuai dapat menurunkan terjadinya kecenderungan kecurangan akuntansi pada PERUMDA BPR Majalengka

Majalengka. Artinya menunjukan bahwa pemberian kompensasi yang sesuai tidak menurunkan kecenderungan kecurangan akuntansi.

3. Pengendalian internal dan kesesuaian kompensasi berpengaruh terhadap kecenderungan kecurangan akuntansi pada PERUMDA BPR Majalengka. Artinya pengendalian internal dan kesesuaian kompensasi yang maksimal akan menurunkan kecenderungan kesesuaian kompensasi. 


\section{ENTREPRENEUR}

\section{Jurnal Bisnis Manajemen Dan Kewirausahaan}

\section{Program Studi Manajemen Fakultas Ekonomika dan Bisnis Universitas Majalengka} Published every January and July e-ISSN : (Proses), p-ISSN: 2723-1941

Available online http://ejournal.unma.ac.id/index.php/entrepreneur

\section{DAFTAR PUSTAKA}

Abdul, Halim. 2015. Auditing (Dasar-Dasar Audit Laporan Keuangan). Jilid I. Edisi Kelima. UPP STIM YKPN: Yogyakarta.

Adelin. 2017. Pengaruh Pengendalian Internal, Ketaatan Pada Aturan akuntansi dan Kecenderungan Terhadap perilaku Tidak Etis. Padang: WRA. Vol 1, Nomor 2.

Agoes, Sukrisno. 2015. Auditing Petunjuk Praktis Pemeriksaan Akuntan oleh Akuntan Publik. Edisi ke 4. Buku 1. Jakarta: Salemba Empat.

Andi. 2014. Pengaruh Keefektivan Pengendalian Internal, Persepsi Kesesuaian Kompensasi, dan Moralitas Individu Terhadap Kecenderungan Kecurangan Akuntansi. Jakarta: Ultima Akunting. Vol. 6 Nomor 1.

Friskia. 2015. Analisis Faktor-Faktor yang Berpengaruh Terhadap Kecenderungan Kecurangan Akuntansi dengan Perilaku Tidak Etis Sebagai Intervening. Jurnal Skripsi Universitas Diponegoro Semarang.

Friskilla. 2014. Pengaruh Moralitas Individu dan Pengendalian Internal Terhadap Kecurangan : Sebuah Studi Eksperimen. Jurnal Investasi dan Akuntansi. Vol. 18 Nomor 2.
Hasibuan. 2016. Pengaruh Moralitas, Integritas, Komitmen Organisasi, dan Pengendalian Internal Kas Terhadap Pencegahan Kecurangan Dalam Pelaksanaan Program Subsidi Beras bagi Masyarakat Berpendapatan Rendah (Studi Pada Desa Kabupaten Buleleng). E-Jurnal S1 Ak Universitas Pendidikan Ganesha. Vol 8 No. 2.

Kennneth. 2014. Sistem Informasi Manajemen: Mengelola Perusahaan Digital, Edisi 8, Yogyakarta: Andi.

Konrath, Larry F. 2014. Auditing: A Risk Analysis Approach. Fifth Edition. South Western.

Lestari. 2017. Pengaruh Pengendalian Internal, Integritas, dan Asimetri Informasi pada Kecurangan Akuntansi. E-Jurnal Akuntansi Universitas Udayana.Vol 21 No. 1 ISSN: 2302-8556.

Lutfi Haris. 2018. Pengaruh Pengendalian Internal dan Asimetri Informasi Terhadap Kecenderungan Kecurangan Akuntansi (Studi Penelitian Persepsi Pengelola Keuangan pada Perguruan Tinggi Negeri $B L U$ )

Maria M. Ratnasari. 2017. Pengaruh Pengendalian Internal dan Moralitas Individu Terhadap Kecenderungan Kecurangan Akuntansi.

Riska. 2018. Pengaruh Moralitas Individu, Efektivitas Pengendalian Internal, Asimetri Informasi, Ketaatan Aturan akuntansi, dan Perilaku Tidak etis Terhadap Kecenderungan Kecurangan Akuntansi. 


\section{ENTREPRENEUR}

\section{Jurnal Bisnis Manajemen Dan Kewirausahaan}

\section{Program Studi Manajemen Fakultas Ekonomika dan Bisnis Universitas Majalengka} Published every January and July e-ISSN : (Proses), p-ISSN: 2723-1941 Available online http://ejournal.unma.ac.id/index.php/entrepreneur

Ryan. 2017. Pengaruh Kesesuaian Kompensasi, Penerapan Sistem Informasi Akuntansi, dan Efektivitas Pengendalian Internal Terhadap Kecurangan Akuntansi.

Veithzal Rival. 2015. Manajemen Sumber Daya Manusia untuk Perusahaan, Edisi ke 6, PT. Raja Grafindo Persada, Depok, 16956.

Zaenal. 2015. Pengaruh Efektivitas Pengendalian Internal, Asimetri Informasi, dan Kesesuaian Informasi Terhadap Kecenderungan Kecurangan Akuntansi (Fraud). Skripsi Fakultas Ekonomi Universitas Negeri Padang. 